\title{
Clinical analysis of gynecological diseases in postmenopausal women in tertiary care centre
}

\section{Bharti Choudhary Parihar*, Priyanka Tiwari}

\begin{abstract}
Department of Obstetrics and Gynecology, Sultania Zanana Hospital, Gandhi Medical College, Bhopal, Madhya
\end{abstract} Pradesh, India

Received: 06 March 2018

Accepted: 12 March 2018

*Correspondence:

Dr. Bharti Choudhary Parihar,

E-mail: drbhartiparihar@gmail.com

Copyright: () the author(s), publisher and licensee Medip Academy. This is an open-access article distributed under the terms of the Creative Commons Attribution Non-Commercial License, which permits unrestricted non-commercial use, distribution, and reproduction in any medium, provided the original work is properly cited.

\begin{abstract}
Background: Menopause is a natural step in ageing process represents the period end of menstruation after last menstrual period in previous 12 months. Gynaecological disorder in older women differs from those who are younger. Disorders peculiar to ageing are pelvic organ prolapse, urinary incontinence, genital infections and malignancies. Present study is contemplated with a view to assess the magnitude of postmenopausal gynaecological morbidity. The goal of this study was to assess the age of onset of menopause and the spectrum of different gynaecological diseases, their incidence, diagnosis and treatment modality in postmenopausal females.

Methods: A Prospective observational study of postmenopausal females attending Gynecology OPD or admitted in Sultania Zanana Hospital, Bhopal was carried out between July 2014 to June 2015. Total 401 postmenopausal females were included. Age of menopause and detail of all gynecological problems were recorded using predesigned proforma.

Results: The study population was drawn from both rural $(41.4 \%)$ and urban $(58.8 \%)$ areas. Mean age of onset of menopause was 48.01 years in study population. In all, $28.4 \%$ had pelvic organ prolapse, $26.6 \%$ had genital malignancies, $25.5 \%$ had urogenital infections and $17.7 \%$ had benign disorder like senile endometritis, fibroid uterus etc.

Conclusions: Menopausal health has been one of the neglected area in our country and needs timely vital attention as they are at risk of developing various genital malignancies. This emphasises the need for a screening programme for Indian women in our scenario.
\end{abstract}

Keywords: Gynaecological disorders, Genital malignancy, Postmenopausal bleeding, Pelvic organ prolapse

\section{INTRODUCTION}

Menopause is not a disease or illness, but it is a natural event in the life of women. Menopause is the permanent cessation of menstruation at the end of reproductive life due to loss of ovarian follicular activity. It is a hypooestrogenic state. It occurs gradually in women and it indicates the transition from reproductive to post reproductive era of women's life. Population ageing is emerging as a pre-eminent phenomenon throughout the world. Among the aged women deserve special attention because they outlive men in most society. This longevity also makes them vulnerable to different morbidity of which Gynaecological disorders remain hidden a hithero neglected because of the 'culture of science' surrounding women lives.

A major challenge for the world in $21^{\text {st }}$ century is the ageing of its population. The older population is growing fastest in India. The number of people aged $>60$ years has grown from $5.4 \%$ in 1981 to $7.5 \%$ in 2001 and it projected to become $12.5 \%$ in $2025 .{ }^{1,2}$ 
Prevalence of gynaecological morbidity varies between 92-95\% among women of all age groups combined. ${ }^{3,4}$ They are influenced by socio cultural, demographic and behavioural factor. ${ }^{5}$

Gynaecological disorders in older women differ from those who are younger. Gynaecological disorders peculiar to aging are pelvic organ prolapse, genitourinary infections and malignancies.

Genital tract malignancies contribute $14 \%$ of cancers in women. The spectrum of gynaecological disorders in India differs from that in developed countries as there are no screening programs for early detection and hardly any dedicated geriatric units.

Therefore, there is an obvious need for providing geriatric gynaecological services, but a paucity of data regarding gynaecological morbidity in postmenopausal women hampers proper planning. Hence present study is contemplated with a view to assess the magnitude of gynaecological morbidity.

The goal of this study was to assess the age of onset of menopause and the spectrum of different gynaecological diseases, their incidence, diagnosis and treatment modality in postmenopausal females.

\section{METHODS}

This study is a hospital based prospective observational study of the postmenopausal females attending gynecological OPD or admitted in department of obstetrics and Gynecology, Gandhi Medical College, Sultania Zanana Hospital, Bhopal from 1st July 2014 to 30th June 2015. Study was conducted after taking approval from ethical committee.

\section{Inclusion criteria}

Postmenopausal females presenting with gynaecological complains

\section{Exclusion criteria}

- Postmenopausal females presenting with breast disorders/medical/surgical illness

- Refusal for participation in study

All patients were explained in detail about aim, objectives of study and written consent was taken. Patient's socio demographic profile, obstetrics and gynaecological history were recorded; including age and type of menopause, menstrual cycle before menopause and how it was attained was noted.

A thorough general physical examination of patient including height, weight, body mass index, pallor, vital data and examination for goitre followed by through systemic examination was done.

\section{Pelvic examination}

Local examination of external genitalia was done for any growth over vulva, urethral orifice and any discharges were noted.

Per speculum examination was done for any growth on cervix, polyp, cervicitis or any bleeding or discharge coming through the os. Thorough inspection of vagina was done for any lesion, varicosity, haemorrhagic spot or atrophic changes. Degree of Cervical descent, cystocoele, rectocoele and enterocoele was noted.

Bimanual examination was done for consistency of cervix, the status of uterus, its size, position, mobility, surface contour, consistency and adenexa for any mass, thickening and tenderness were assessed.

Per rectal examination was done whenever required to find out involvement of the rectal mucosa, any mass in Rectum, involvement of the parametrium or any secondaries in Pouch of Douglas.

Laboratory investigations including complete haemogram, blood biochemistry, urine examination, pap smear, pelvic ultrasonography, electrocardiography, x-ray and computer tomography (in cases of genital malignancies) was done. Resected tissues (in operated cases) were examined histopathologically. Details of all gynaecological problems were recorded using predesigned proforma.

Postmenopausal bleeding was defined as vaginal bleeding 12 months after spontaneous amenorrhoea. Diagnostic dilatation and curettage to obtain endometrial tissue and in unhealthy cervix, cervical tissue were examined histopathologically.

Atrophic vaginitis is defined as thinning of vaginal walls caused by decreased oestrogen levels accompanied by purulent discharge with atrophy of external genitalia and loss of vaginal rugae.

Urinary incontinence was defined as any involuntary leakage of urine. Stress urinary incontinence was associated with increased intra abdominal pressure.

Urinary tract infection, pelvic organ prolapse, degree of cystocele, uretrocele, rectocele, enterocele and genital malignancy were also assessed.

The data collected was tabulated in Microsoft excel sheet and were statistically analysed.

\section{RESULTS}

During study period total 3966 women attended our OPD for various reasons, out of which 401 i.e. approximately $9.8 \%$ were menopausal women. The study population 
was drawn from both rural $(41.4 \%)$ and urban $(58.8 \%)$ area.

Table 1: Age wise distribution of postmenopausal patients (n-401).

\begin{tabular}{|lll|}
\hline Age (years) & No. & Percentage (\%) \\
\hline $40-50$ & 159 & 39.6 \\
\hline $51-60$ & 144 & 35.9 \\
\hline $61-70$ & 91 & 22.6 \\
\hline$>70$ & 7 & 1.74 \\
\hline
\end{tabular}

Maximum number of women were in age group of 40-50 years $(39.6 \%)$ followed by $50-60$ years $(35.9 \%)$.

Table 2: Distribution according to duration of menopause.

\begin{tabular}{|lll|}
\hline $\begin{array}{l}\text { Duration of } \\
\text { menopause (years) }\end{array}$ & $\begin{array}{l}\text { No. of patients } \\
(\mathrm{n}-401)\end{array}$ & Percentage \\
\hline 1-5 years & 158 & 39.40 \\
\hline 6-10 years & 121 & 30.17 \\
\hline 11-15 years & 45 & 11.22 \\
\hline 16-20 years & 60 & 14.96 \\
\hline 21-30 years & 17 & 4.23 \\
\hline
\end{tabular}

In maximum numbers of patients, $158(39.40 \%)$, the duration of menopause was between 1-5 years. Duration of menopause is inversely related to postmenopausal bleeding.

Table 3: Distribution of presenting complaints in postmenopausal patients.

\begin{tabular}{|c|c|c|}
\hline Presenting complaints & $\begin{array}{l}\text { No. of } \\
\text { patients } \\
(\mathrm{N}=401)\end{array}$ & Percentage \\
\hline $\begin{array}{l}\text { Something coming out } \\
\text { from private part }\end{array}$ & 105 & 26.1 \\
\hline Post menopausal bleeding & 94 & 23.4 \\
\hline lower abdominal pain & 80 & 19.9 \\
\hline Discharge per vagina & 75 & 18.7 \\
\hline Urinary problems & 70 & 17.4 \\
\hline Abdominal distension & 22 & 5.4 \\
\hline Loss of appetite & 7 & 1.7 \\
\hline Itching over private parts & 6 & 1.4 \\
\hline constipation & 4 & 0.9 \\
\hline
\end{tabular}

Maximum number of women having presenting complains of something coming out from private parts (26.1\%) followed by postmenopausal bleeding (23.4\%) and lower abdominal pain (19.9\%).

The most common Gynaecological disorder was uterovaginal prolapse $(\mathrm{n}-114,28.4 \%)$ followed by malignant disorders of genital tract (n-107, 26.6\%), urogenital infections (n-103, 25.5\%) and benign disorders of genital tract $(17.7 \%)$.
Pelvic organ prolapse is an increasing common condition seen in women with the aging of population. Results are statistically highly significant $(\mathrm{p}<0.01)$.

Table 4: Distribution of gynaecological disorders in postmenopausal patients.

\begin{tabular}{|c|c|c|c|}
\hline \multicolumn{2}{|c|}{ Disease Profile } & $\begin{array}{l}\text { No. of } \\
\text { patients } \\
(n-401)\end{array}$ & Percentage \\
\hline \multicolumn{2}{|c|}{ Uterovaginal prolapse } & 114 & 28.4 \\
\hline \multirow{4}{*}{$\begin{array}{l}\text { Malignant } \\
\text { Disorders } \\
\text { (n-107, } \\
26.6 \%)\end{array}$} & $\begin{array}{l}\text { Carcinaoma } \\
\text { cervix }\end{array}$ & 82 & 20.4 \\
\hline & $\begin{array}{l}\text { Carcinoma } \\
\text { ovary }\end{array}$ & 15 & 3.74 \\
\hline & $\begin{array}{l}\text { Carcinoma } \\
\text { endometrium }\end{array}$ & 8 & 1.99 \\
\hline & $\begin{array}{l}\text { Vault } \\
\text { carcinoma }\end{array}$ & 2 & 0.49 \\
\hline \multirow{5}{*}{$\begin{array}{l}\text { Urogenital } \\
\text { infection } \\
\text { (n- } \\
103,25.6 \%)\end{array}$} & $\begin{array}{l}\text { Urinary Tract } \\
\text { Infection }\end{array}$ & 43 & 10.7 \\
\hline & Pyometra & 20 & 4.98 \\
\hline & $\begin{array}{l}\text { Chronic } \\
\text { cervicitis }\end{array}$ & 16 & 3.99 \\
\hline & PID & 7 & 1.74 \\
\hline & $\begin{array}{l}\text { Senile } \\
\text { vaginitis }\end{array}$ & 17 & 4.23 \\
\hline \multirow{5}{*}{$\begin{array}{l}\text { Benign } \\
\text { disorders of } \\
\text { genital tract } \\
(n- \\
73,18.2 \%)\end{array}$} & $\begin{array}{l}\text { Atrophic } \\
\text { endometritis }\end{array}$ & 36 & 8.97 \\
\hline & Fibroid uterus & 18 & 4.5 \\
\hline & $\begin{array}{l}\text { Benign } \\
\text { ovarian mass }\end{array}$ & 12 & 2.99 \\
\hline & $\begin{array}{l}\text { Endometrial } \\
\text { polyp }\end{array}$ & 5 & 1.24 \\
\hline & Bartholin cyst & 2 & 0.49 \\
\hline \multicolumn{2}{|c|}{$\begin{array}{l}\text { Pre-malignant disorders of } \\
\text { genital tract }\end{array}$} & 3 & 0.74 \\
\hline \multicolumn{2}{|c|}{ Urethral caruncle } & 1 & 0.24 \\
\hline
\end{tabular}

Out of 114 cases of uterovaginal prolapse, maximum number of patients had third degree prolapse uterus (79.8\%) followed by procidentia $(11.4 \%), 2$ cases $(1.7 \%)$ had vault prolapse.

Out of 107 cases of genital malignancy, Carcinoma of the cervix was the commonest malignancy in our study (n$82,20.4 \%$ ) followed by carcinoma ovary (n-15, 3.74\%), carcinoma endometrium (n-8, 1.99\%) and vault carcinoma (n-2, 0.49\%).

Out of 103 cases of urogenital infection, maximum patients had Urinary tract infection $(10.7 \%)$ followed by pyometra $(4.98 \%)$, chronic cervicitis $(3.99 \%)$, senile vaginitis $(4.23 \%)$ and PID (1.74\%).

Benign disorders of genital tract were 73. Maximum number of women had Atrophic endometritis (8.97\%) followed by fibroid uterus $(4.5 \%)$, benign ovarian mass 
(2.99\%), endometrial polyp (1.24\%) and Bartholin cyst $(0.49 \%)$.

Most common surgery performed for UV prolapse was vaginal hysterectomy followed by anterior calporrhaphy with posterior calpoperineorrhaphy $(96.6 \%)$.

Table 5: Type of surgery performed for UV Prolapse (n-106).

\begin{tabular}{|lll|}
\hline Type of Surgery & No. & Percentage \\
\hline Vaginal hysterectomy & 2 & 1.9 \\
\hline $\begin{array}{l}\text { Vaginal hysterectomy with } \\
\text { anterior calporrhaphy with } \\
\text { posterior calporrhaphy }\end{array}$ & 102 & 96.2 \\
$\begin{array}{l}\text { Vault suspension by } \\
\text { sacrocolpopexy }\end{array}$ & 2 & 1.9 \\
\hline
\end{tabular}

The most common surgery performed for gynaecological malignancy was staging laparotomy (TAH with BSO with omentectomy 60.5\%) for ovarian malignancy followed by Wertheim's Hysterectomy (29\%) for carcinoma cervix.

Table 6: Type of surgery performed for genital malignancies (n-38).

\begin{tabular}{|l|ll|}
\hline Type of Surgery & No. & Percentage \\
\hline TAH (CIN) & 4 & 10.5 \\
\hline $\begin{array}{l}\text { Staging laparotomy (TAH with } \\
\text { BHO with Omentectomy) }\end{array}$ & 23 & 60.5 \\
\hline Wertheim's Hysterectomy & 11 & 29 \\
\hline
\end{tabular}

\section{DISCUSSION}

In present study, age range was 40-50years (39.6\%) followed by $50-60$ years $(35.9 \%)$.

Table 7: Comparison of age of presentation with other studies.

\begin{tabular}{|c|c|c|c|}
\hline Authors & $\begin{array}{l}\text { Sample } \\
\operatorname{size}(\mathbf{n})\end{array}$ & $\begin{array}{l}\text { Age } \\
\text { range } \\
\text { (years) }\end{array}$ & $\begin{array}{l}\text { mean } \\
\text { age } \pm \text { SD } \\
\text { (years) }\end{array}$ \\
\hline Lidor A et al ${ }^{6}$ & 226 & $40-81$ & 56 \\
\hline $\begin{array}{l}\text { Gredimark } \mathrm{T} \text { et } \\
\mathrm{al}^{7}\end{array}$ & 457 & $50-80$ & - \\
\hline Singh $\mathrm{A}$ at $\mathrm{al}^{8}$ & 100 & $40-75$ & - \\
\hline Opmeer $\mathrm{B}$ et $\mathrm{al}^{9}$ & 540 & $37-91$ & $62 \pm 10$ \\
\hline Bharti B et al ${ }^{10}$ & 25 & $52-65$ & $55.25 \pm 3.84$ \\
\hline Present study & 401 & $40-68$ & 56.6 \\
\hline
\end{tabular}

It was observed that maximum number of patients 59 (37.11\%) had menopause between $46-50$ years. Mean age was $48.10 \pm 2.8$ years.

The duration of menopause was calculated by taking time interval between onset of menopause and onset of complains (postmenopausal bleeding, prolapse etc).
Table 8: Comparison of mean age of menopause with other studies.

\begin{tabular}{|ll|}
\hline Authors & $\begin{array}{l}\text { Mean age at } \\
\text { menopause (years) }\end{array}$ \\
\hline Opmeer B et al & \\
\hline Bharani Bharti et al $^{10}$ & $50 \pm 4.9$ \\
\hline Present study & $55.24 \pm 3.84$ \\
\hline
\end{tabular}

In maximum number of cases, the duration of menopause was between $6-10$ years.

The most common presenting complaint in present study was something coming out from private parts $(26.1 \%)$ followed by postmenopausal bleeding (23.4\%).

Okeke TC et al conducted a retrospective study of vaginal prolapse commonest symptom was something coming down the vagina in $96 \%$ of the study subjects. ${ }^{11}$

Rehana Rahim and Nasreen Ruby et al in 2001 conducted a study on postmenopausal women. Results showed that main gynaecological complain was pressure perineum followed by urinary complains. ${ }^{12}$

$70 \%$ cases of post menopausal bleeding have an innocent or harmless cause of bleeding but $30 \%$ of them are associated with malignancies. Hence post menopausal bleeding requires a thorough evaluation clinically and pathologically to exclude carcinoma as the cause and ensure a benign pathology.

Debnath $\mathrm{S}$ et al in their study at JIPMER Hospital, Pondicherry on 500 post menopausal women found neoplasm in $52 \%$ of cases and carcinoma cervix accounted for $42 \%$ of total cases. ${ }^{13}$

Carlos RC et al reported that postmenopausal bleeding represents approximately $5 \%$ of all gynaecological visits. $^{14}$

Present study showed that maximum number of women had uterovaginal prolapse $(28.4 \%)$ followed by genital malignancies $(26.6 \%)$ followed by urogenital infections (25.5\%) and benign disorders of genital tract (17.7\%).

Takkar $\mathrm{N}$ et al reported most common gynaecological disorder in older women was pelvic organ prolapse in $28 \% .^{15}$

Okeke TC et al in conduct a retrospective study of uterovaginal prolapse, $74 \%$ of them were post menopausal. Second degree prolapse was the commonest type of presentation (48\%) and the definitive treatment modality was vaginal hysterectomy with pelvic floor repair $(44 \%)$.

In present study, out of total 180 patients with postmenopausal bleeding, 107 were due to benign lesions and 73 cases were due to malignant lesions. Out of total 73 cases of malignancy, Carcinoma cervix was the 
commonest malignancy $(20.4 \%)$ ) followed by carcinoma ovary $(3.74 \%)$. Perhaps the high incidence of malignancy is due to the fact that our hospital is a referral centre and hence cases of malignancy are referred here from nearby area.

Lee WH et al in a study of 163 patients with postmenopausal bleeding found malignant causes in $25.7 \%$ cases, of which the most common malignancy was cervical carcinoma (12.9\%) followed by endometrial carcinoma (11\%). ${ }^{16}$ Important benign cause was cervicitis $(12.9 \%)$, atrophic vaginitis $(12.3 \%)$, cervical polyp $(6.7 \%)$, endometrial hyperplasia $(3.1 \%)$, urethral caruncle $(2.5 \%)$ and estrogen replacement therapy (1.8\%)

Most common surgery performed for gynaecological malignancies was staging laparotomy (TAH with BSO with omentectomy in 60.5\%) followed by Wertheim's Hysterectomy (29\%).

Six patients of stage I and five patients of stage IIA carcinoma cervix underwent Wertheim Hysterectomy. Rest of cases of cervical carcinoma (n-70) were advanced cancer and treated with radiotherapy and chemotherapy

Somalwar SA et al on postmenopausal women, malignancy was confirmed in $27.5 \%$ women. ${ }^{17}$ Carcinoma endometrium was found in $9.09 \%$ of total malignancies. All these women underwent surgery. Out of these $60 \%$ received chemotherapy postoperatively.

In present study, $73(18.2 \%)$ of women were admitted for benign disorder of genital tract. Maximum number of women having Atrophic endometritis (8.97\%) followed by fibroid uterus (4.5\%), Benign ovarian mass $(2.99 \%)$, Endometrial polyp (1.24\%) and Bartholin cyst (0.49\%)

Moodly $\mathrm{M}$ et al in their study of postmenopausal patients found Benign lesions in 35\% cases and malignancy in $65 \%$ cases. $^{18}$ Cervical polyp was the most common benign lesion (43\%) followed by atrophic vaginitis $(33 \%)$.

36 postmenopausal women having atrophic vaginitis managed conservatively. All cases of benign ovarian mass and fibroid uterus (n-30) were managed by total abdominal Hysterectomy. Five women having endometrial polyp underwent polypectomy. Two women having Bartholin cyst underwent marsupilization operation.

\section{CONCLUSION}

To conclude, pelvic organ prolapse, postmenopausal bleeding and urogenital infection were the major gynaecological problems in older women. Postmenopausal bleeding is a common feature of underlying gynaecological malignancy in such women. Urgent referral for gynaecological work up is warranted. Carcinoma of the cervix was the commonest cause of postmenopausal bleeding. The high incidence of cervical cancer observed in our study, emphasises the urgent need for a national screening programme for postmenopausal women.

Type and management of gynaecologic problems in women aged over 65 can be challenging and differ from those for younger women. Thus, caring for these women in their reproductive years as well as in later life should be an aim for all obstetrician-gynaecologists. Therefore, there is an obvious need for providing geriatric gynaecological services, but paucity of data regarding gynaecological morbidity in postmenopausal women hampers proper planning. Hence, present study is contemplated with a view to assess the magnitude of post menopausal Gynaecological morbidity.

\section{ACKNOWLEDGMENTS}

Authors would like to thank to all patients for their cooperation and postgraduate students and teachers for their overwhelming support.

Funding: No funding sources

Conflict of interest: None declared

Ethical approval: The study was approved by the Institutional Ethics Committee

\section{REFERENCES}

1. Census of India 2001. Available at http:/ / www.censusindia.govt. in /census_Data_2001/India _at glance / broad aspx. Accessed on 2 October 2009

2. World Health Organization. Available at www. Whoindia.Org/../Health_care_for_the_older_INTRA _country_profile wo.pdf. Accessed on 2 October 2009

3. Bang RA, Baitule M, Sarmukaddam S, Bang AT, Choudhary Y, Tale O. et al. High prevalence of Gynaecological disease in rural Indian women. Lancet. 1989;1:85-8.

4. Sehgal A, Singh A, Kumar R, Gupta I. A selection of essays: an epidemiological study of gynecological morbidity in a rural community of Haryana, India. Contraception. 1995;50:22.

5. Zuray H, Khottab, Younis V. Concepts and measure of reproductive morbidity. Health Transit Rev 1993;3(1):17-9.

6. Lidor A, Ismajovich B, Coinfino E, David MP. Histopathological findings in 226 women with postmenopausal bleeding. Acta Obstet Gynaecol Scand. 1996;65:4143-5.

7. Gredmark T, Kvint S, Hovel G, Mattson IA. Histological finding in women with postmenopausal bleeding. Br J Obstet Gynaecol 2001;102:133-6.

8. Singh A, Arora S. The Red Alert post menopausal bleeding. Br J Obstet Gynecol. 2005;10:592-6.

9. Opmeer BC, Van Doom HC, Heintz AP, Burger CW. Improving the diagnostic strategy by accounting for characteristics of women in the 
diagnostic work up for postmenopausal bleeding. BJOG. 2007;114:51-8.

10. Bharani B, Phatak SR. Feasibility and yield of endometrial biopsy using suction curette device for evaluation of abnormal pre and postmenopausal bleeding. J Obstet Gynaecol India. 2008;58(4):322-6.

11. Okeke TC. An audit of utero-vaginal prolapse in Enugu, Suthest Nigeria. Am J Clini Med Res. 2013;1(1):23-5.

12. Rahim R, Faiz NR. Gynaecological problems in the postmenopausal women. JPMI. 1993;7 (2):28-31.

13. Debnath S, Gita R, Arora R, Rajaram P. A study of gynaecological problems in post menopausal women. J Obstet Gyn Ind. 2004;44:286-9.

14. Carlos RC, Robert L, Br asee Abrishamse PH. Cost effectiveness of saline assisted hysterosonography and office hysteroscopy in evaluation of post menopausal bleeding. Acad Radiole. 2001;8:835-44.

15. Takkar N, Goel P, Dua D, Mohan H. Spectrum of Gynecological disorder in older Indian Women. Asian J Gerontol. 2010;5:69-73.
16. Lee WH, Tan KH, Lee YW. The aetiology of post menopausal bleeding. A study of 163 consecutive cases in Singapore. Singapore Med J. 1995;36(2):164-8.

17. Somalwar SA, Joshi S, Kawthalkar A, Bhalerao A, Jain S, Somalwar A. Analysis of Genital Tract Malignancies in Postmenopausal Indian Women. J SAFOMS. 2013 Jul 1;1(2):66-69.

18. Moodley M, Robert C. Clinical pathway for the evaluation of postmenopausal bleeding with an emphasis on endometrial cancer detection. Obst Gynae Tosay. 2005;10(10):592-3.

Cite this article as: Parihar BC, Tiwari P. Clinical analysis of gynecological diseases in postmenopausal women in tertiary care centre. Int J Reprod Contracept Obstet Gynecol 2018;7:1394-9. 